\title{
Pengaruh Strategi Pembelajaran dan Bentuk Tes Formatif Terhadap Hasil Belajar Matematika Dengan Mengontrol Intelegensi Siswa
}

\author{
Lizza Novrida \\ Guru SMP Negeri 11 Jakarta \\ lizzanovrida@gmail.com
}

\begin{abstract}
Abstrak: Penelitian ini bertujuan menemukan pengaruh strategi pembelajaran dan bentuk tes formatif terhadap hasil belajar matematika dengan mengontrol inteligensi siswa. Penelitian ini menggunakan design eksperimen faktorial 2x2. Cluster random sampling dengan 80 siswa kelas delapan di SMPN 11 dan SMPN 19 Jakarta pada tahun ajaran 2009/2010. Variabel bebasnya yaitu strategi pembelajaran dan bentuk tes formatif, serta variabel terikatnya hasil belajar matematika. Inteligensi sebagai co-variabel. Strategi yang digunakan yaitu pemetaan informasi dan konvensional, dan bentuk tes formatif yang digunakan adalah pilihan ganda dan uraian. Hasil penelitian menunjukkan: 1) strategi pemetaan informasi lebih efektif dibanding strategi konvensional; 2) bentuk tes formatif pilihan ganda kurang efektif dibanding bentuk tes formatif uraian, dan 3) terdapat interaksi antara strategi pembelajaran dengan bentuk tes formatif.
\end{abstract}

Kata kunci: hasil belajar matematika, strategi pembelajaran, bentuk tes formatif, dan siswa sekolah menengah pertama

\begin{abstract}
The objectives of this study is to find out the effects of the learning strategy and the formative test on the learning outcome in mathematics. The quasi-experiment with $2 \times 2$ factorial design was used in this research. A cluster random sampling was used for 80 students of grade-2 at the State Junior High Schools number 11 and 19 in Jakarta in 2009-2010. The independent variables were the learning strategy and formative test, and for the dependent variables were learning outcome. The student intelligent was used as a co-variable. The strategy used were the information mapping, and conventional strategy, and the test were multiple choice and essay. The results showed the fallowings: 1) the information mapping strategy is more effective than the conventional way; 2) the multiple choice is better than essay test; 3) there was found an interaction between the learning strategy with the formative test.
\end{abstract}

Key words: math learning outcome, learning strategy test types, and junior high school student

\section{Pendahuluan}

\section{Latar Belakang Masalah}

Pendidikan adalah usaha sadar dan terencana untuk mewujudkan suasana belajar dan proses pembelajaran agar peserta didik secara aktif mengembangkan potensi dirinya untuk memiliki kekuatan spiritual keagamaan, pengendalian diri, kepribadian, kecerdasan, akhlak mulia, serta keterampilan yang diperlukan dirinya, masyarakat, bangsa, dan negara (Undang-Undang Republik Indonesia Nomor 20, 2003: 50).

Sekolah Menengah Pertama merupakan salah satu dari lembaga pendidikan dasar yang berorientasi pada pendidikan umum. Lembaga pendidikan ini memberikan kemampuan dan keterampilan kepada siswanya agar memiliki bekal ilmu apabila kelak mereka meninggalkan bangku sekolah.

Hasil belajar menunjuk pada prestasi belajar, sedangkan prestasi belajar itu merupakan indikator adanya dan derajat perubahan tingkah laku siswa (Soedjadi, 2000: 10). Evaluasi hasil belajar peserta didik dilakukan oleh pendidik untuk memantau proses, kemajuan, dan perbaikan hasil belajar peserta didik secara kesinambungan (Undang-Undang Republik Indonesia Nomor 20, 2003: 38). Selanjutnya ditentukan bahwa "Evaluasi peserta didik, satuan pendidikan dan program pendidikan dilakukan oleh lembaga mandiri secara berkala, menyeluruh, transparan, dan sistemik untuk menilai pencapaian standar 
nasional pendidikan" (Undang-undang Republik Indonesia Nomor 20, 2003: 38). Jadi jelas, bahwa bukan hanya guru yang berkeinginan untuk meningkatkan keberhasilan siswa, mulai dari tingkat satuan pendidikan sampai tingkat nasional bersama-sama berusaha meningkatkan hasil belajar melalui evaluasi.

Matematika adalah salah satu mata pelajaran yang diwajibkan untuk diikuti semua siswa, karena berfungsi sebagai jembatan pengetahuan matematika di Sekolah Dasar (SD) dengan Sekolah Menengah Atas (SMA), dan memberikan dasar pengetahuan matematika untuk pelajaran yang lain. Untuk itu peneliti menggunakan matematika sebagai mata pelajaran yang perlu ditingkatkan hasil belajarnya agar dapat menjadi jembatan pengetahuan dari SD dengan SMA.

Dari hasil belajar yang diperoleh siswa pada saat Ujian Nasional (UN) untuk mata pelajaran Bahasa Indonesia $(7,86)$, Bahasa Inggris $(7,29)$, Matematika $(7,06)$ dan IPA $(7,22)$ (Berita Jakarta. Com, 2008:1), diketahui bahwa pada mata pelajaran matematika siswa diperoleh nilai yang terendah dibandingkan dengan nilai mata pelajaran lain. Keadaan ini merupakan masalah yang sangat memprihatinkan bagi semua pihak, terutama yang menaruh perhatian kepada hasil UN mata pelajaran matematika. Untuk itu, perlu upaya perbaikan yang dapat meningkatkan hasil belajar matematika khususnya pada sekolah menengah pertama.

Perlu dilakukan suatu kajian secara cermat dan mendalam mengenai faktor-faktor yang diduga mempengaruhi hasil belajar matematika siswa. Faktor yang mempengaruhi hasil belajar matematika ada dua yaitu faktor internal dan faktor eksternal. Faktor internal adalah faktor yang berasal dari dalam diri individu. Faktor eksternal yaitu faktor yang berasal dari luar individu (Woolfolk, 1993: 197). Dari faktor internal dan faktor eksternal inilah peneliti akan mengkaji dua faktor yaitu faktor eksternal dari faktor kurikulum sekolah, khususnya bentuk tes formatif dan faktor strategi pembelajaran.

Strategi pembelajaran konvensional yang selama ini diterapkan akan diubah dengan strategi pembelajaran pemetaan informasi yang menitikberatkan pada peran guru sebagai fasilitator. Bentuk tes formatif yang akan digunakan adalah bentuk tes formatif pilihan ganda karena dapat melatih siswa menghadapi ujian nasional yang mempunyai bentuk tes pilihan ganda dan bentuk tes uraian agar dapat melatih siswa menuangkan kemampuan menguraikan hal yang diketahui terutama tentang materi yang telah dipelajari. Faktor strategi pembelajaran dan faktor bentuk tes formatif inilah yang akan diselidiki pengaruhnya terhadap hasil belajar matematika pada siswa kelas 8 pada Sekolah Menengah Pertama (SMP) di Jakarta setelah mengontrol inteligensi siswa.

Bertitik tolak dari uraian yang telah dikemukakan di atas, maka secara umum masalah penelitian adalah bagaimana pengaruh strategi pembelajaran, bentuk tes formatif dan inteligensi siswa terhadap hasil belajar matematika siswa? Secara rinci, masalah dalam penelitian ini yaitu: 1) apakah terdapat perbedaan hasil belajar matematika siswa yang menggunakan strategi pemetaan informasi dengan hasil belajar matematika siswa yang menggunakan strategi konvensional setelah mengontrol inteligensi siswa?; 2) apakah terdapat perbedaan hasil belajar matematika siswa yang diberikan bentuk tes formatif pilihan ganda dengan hasil belajar matematika siswa yang diberikan bentuk tes formatif uraian setelah mengontrol inteligensi siswa?; 3) apakah terdapat pengaruh interaksi antara strategi pembelajaran dan bentuk tes formatif terhadap hasil belajar matematika setelah mengontrol inteligensi siswa?; 4) untuk siswa yang diberikan bentuk tes formatif pilihan ganda, apakah hasil belajar matematika siswa yang menggunakan strategi pemetaan informasi berbeda dengan hasil belajar matematika siswa yang menggunakan strategi konvensional setelah mengontrol inteligensi siswa?; 5) untuk siswa yang diberikan bentuk tes formatif uraian, apakah hasil belajar matematika siswa yang menggunakan strategi pemetaan informasi berbeda dengan hasil belajar matematika siswa yang menggunakan strategi konvensional setelah mengontrol inteligensi siswa?; 6) untuk siswa yang menggunakan strategi pemetaan informasi, apakah hasil belajar matematika siswa yang diberikan bentuk tes formatif pilihan ganda berbeda dengan hasil belajar matematika siswa yang diberikan bentuk tes formatif uraian setelah mengontrol inteligensi siswa?; dan 7) untuk siswa yang 
menggunakan strategi konvensional, apakah hasil belajar matematika siswa yang diberikan bentuk tes formatif pilihan ganda berbeda dengan hasil belajar matematika siswa yang diberikan bentuk tes formatif uraian setelah mengontrol inteligensi siswa?.

Sesuai dengan latar belakang masalah dan perumusan masalah, penelitian ini bertujuan untuk melihat: 1) perbedaan hasil belajar matematika siswa yang menggunakan strategi pemetaan informasi dengan hasil belajar matematika siswa yang menggunakan strategi konvensional setelah mengontrol inteligensi siswa?; 2) perbedaan hasil belajar matematika siswa yang diberikan bentuk tes formatif pilihan ganda dengan hasil belajar matematika siswa yang diberikan bentuk tes formatif uraian setelah mengontrol inteligensi siswa?; 3) pengaruh interaksi antara strategi pembelajaran dan bentuk tes formatif terhadap hasil belajar matematika setelah mengontrol inteligensi siswa?; 4) untuk siswa yang diberikan bentuk tes formatif pilihan ganda, apakah hasil belajar matematika siswa yang menggunakan strategi pemetaan informasi berbeda dengan hasil belajar matematika siswa yang menggunakan strategi konvensional setelah mengontrol inteligensi siswa?; 5) untuk siswa yang diberikan bentuk tes formatif uraian, apakah hasil belajar matematika siswa yang menggunakan strategi pemetaan informasi berbeda dengan hasil belajar matematika siswa yang menggunakan strategi konvensional setelah mengontrol inteligensi siswa?; 6) untuk siswa yang menggunakan strategi pemetaan informasi, apakah hasil belajar matematika siswa yang diberikan bentuk tes formatif pilihan ganda berbeda dengan hasil belajar matematika siswa yang diberikan bentuk tes formatif uraian setelah mengontrol inteligensi siswa?; dan 7) untuk siswa yang menggunakan strategi konvensional, apakah hasil belajar matematika siswa yang diberikan bentuk tes formatif pilihan ganda berbeda dengan hasil belajar matematika siswa yang diberikan bentuk tes formatif uraian setelah mengontrol inteligensi siswa?.

\section{Kajian literatur}

\section{Hasil Belajar Matematika}

Seseorang telah belajar jika terdapat perubahan tingkah laku akibat interaksi dengan lingkungan, tidak karena proses pertumbuhan fisik atau kematangan, tidak karena kelelahan, penyakit atau pengaruh obat, dan perubahan tersebut bersifat permanen, tahan lama dan menetap, tidak berlangsung sesaat saja (Sadiman, 2002: 3). Belajar adalah proses yang aktif dan memberikan reaksi terhadap semua situasi yang ada di sekitar individu yang sedang belajar, yang diarahkan kepada tujuan dengan melihat, mengamati serta memahami sesuatu untuk mengubah tingkah laku seseorang pada saat belajar, tingkah laku yang dapat diamati (penampilan), maupun yang tidak dapat diamati (kecenderungan perilaku). Artinya, belajar adalah suatu kegiatan seseorang yang dilakukan dengan sadar atau disengaja sehingga diperoleh kecakapan baru dan terjadi perubahan yang disebut hasil belajar.

Hasil belajar adalah hasil perubahan tingkah laku yang meliputi 3 (tiga) ranah, yaitu kognitif, afektif dan psikomotor (Bloom, 1971: 864 - 865). Hasil belajar seseorang dapat diperoleh melalui seperangkat tes, dari hasil tes tersebut dapat memberikan informasi tentang seberapa jauh kemampuan penyerapan materi oleh siswa setelah mengikuti proses belajar. Hasil belajar dalam penelitian ini adalah kemampuan siswa pada ranah kognitif yang diperoleh setelah mengikuti proses pembelajaran yang terwujud dalam bentuk skor hasil belajar matematika.

Hingga saat ini belum ada definisi matematika yang tunggal dan berlaku secara universal. Para ahli matematika mendefinisikan matematika sesuai dengan bidang keahliannya masingmasing. Contoh-contoh definisi matematika antara lain: 1) cabang ilmu pengetahuan eksak dan terorganisir secara sistematik; 2) pengetahuan tentang bilangan dan kalkulasi; 3) pengetahuan tentang penalaran logik dan berhubungan dengan bilangan; 4) pengetahuan tentang faktafakta kuantitatif dan masalah tentang ruang dan bentuk; 5) pengetahuan tentang struktur-struktur yang logik; dan 6) pengetahuan tentang aturanaturan yang ketat (Soedjadi, 2000: 11).

Fungsi matematika sekolah yaitu: 1) kegiatan penelusuran pola; 2) kreatifitas yang memerlukan imajinasi, intuisi dan penemuan; 3) kegiatan pemecahan masalah (problem solving); dan 4) alat komunikasi (Departemen Pendidikan Nasional, 
2003: 3-4). Artinya matematika Sekolah, menekankan pada penataan nalar, pembentukkan sikap siswa, dan keterampilan dalam penerapan matematika.

Hasil belajar matematika adalah kemampuan siswa pada ranah kognitif yang diperoleh setelah mengikuti proses pembelajaran yang terwujud dalam bentuk skor hasil belajar matematika. Skor hasil belajar matematika pada penelitian ini mengarah pada ranah kognitif taksonomi Bloom, yang dibatasi pada: 1) pengetahuan; 2) pemahaman; 3) aplikasi; dan 4) analisis pada mata pelajaran matematika.

\section{Strategi Pembelajaran}

Strategi pembelajaran merupakan hal yang perlu diperhatikan oleh seorang instruktur, guru, widyaiswara dalam proses pembelajaran dengan 3 jenis strategi yaitu: 1) pengorganisasian; 2) penyampaian; dan 3) pengelolaan. Strategi pembelajaran juga merupakan suatu kegiatan pembelajaran yang harus dikerjakan guru dan siswa agar tujuan pembelajaran dapat di capai secara efektif dan efisien (Departemen Pendidikan Nasional, 2008: 3 - 4). Dengan demikian, strategi pembelajaran adalah kegiatan pengorganisasian bahan ajar, kegiatan penyampaian informasi di dalam kelas, serta kegiatan pengelolaan proses belajar mengajar di kelas.

Strategi pemetaan informasi pada penelitian ini adalah strategi pembelajaran yang menggunakan strategi pemetaan informasi pada waktu pengorganisasian dengan menggunakan peta konsep dan peta prosedur dilengkapi latihan sebagai bahan pengajaran, penyampaian materi pelajaran dengan peta konsep dan peta prosedur, pengelolaan di kelas dengan peran siswa untuk memproses informasi dan guru adalah membimbing dan memberikan sedikit pengarahan dalam proses belajar. Pemetaan informasi adalah memasangkan pada waktu serangkaian tahapantahapan dari proses menulis ke bagian-bagian, seksi-seksi, bab-bab, dan dokumen-dokumen yang berhubungan dengan suatu maksud dari suatu informasi dan kebutuhan untuk membaca (Horn, 1996: 7). Dan salah satu tujuan utama dari pemetaan informasi adalah untuk memberi suatu subjek masalah yang mana akan memberikan suatu pikiran, pengetahuan yang baik dalam mata pelajaran atau menulis suatu pengantar untuk latihan suatu masalah yang berbicara tentang sesuatu (Horn, 1996: 8). Pemetaan informasi yang disesuaikan dengan tingkat pengetahuan siswa yang tidak terlalu tinggi atau tidak terlalu rendah, tetapi pemetaan informasi yang dapat di terima oleh siswa yang mempunyai IQ tinggi maupun siswa yang mempunyai IQ rendah.

Pemetaan informasi yang dapat digunakan untuk merancang dan menyusun bahan pengajaran yang dapat diklasifikasikan ke dalam beberapa kategori informasi, dan kemudian disusun ke dalam suatu bentuk yang terstruktur yang di sebut petapeta informasi, yang berisi peta: struktur, prosedur, proses, klasifikasi, konsep, fakta, dan prinsip. Peta struktur menampilkan struktur dari suatu obyek fisik. Peta prosedur menerangkan bagaimana mengerjakan sesuatu dan bagaimana urutan pengerjaannya. Peta proses menjelaskan bagaimana terjadinya perubahan struktur menurut waktu. Peta konsep mendefinisikan, memberi contoh, dan menampilkan ciri-ciri lain dari suatu konsep. Peta klasifikasi menunjukan bagaimana sekelompok konsep diorganisasikan, dan peta fakta menampilkan hasil observasi atau ukuran. Peta prinsip adalah peta yang menunjukan bagaimana aturan-aturan suatu struktur berlaku (Horn, 1996: 8).

Sebuah peta informasi dibentuk oleh beberapa petak informasi, sebuah petak informasi dibentuk oleh kalimat atau diagram tentang topik yang tak terbatas, pemecahan yang terpadu secara logis, mengidentifikasi secara jelas dengan sebuah label yang menggambarkan fungsi yang berfokus pada pembacaan atau isi petak yang berdasarkan subjek tentang sesuatu. Peta konsep dan peta prosedur dapat digunakan untuk menyusun bahan pengajaran matematika. Untuk menyusun sebuah peta konsep atau peta prosedur terdapat beberapa petak informasi yang dapat digunakan. Ada petak yang perlu dimuatkan ke dalam peta dan ada petak yang dapat di pilih oleh guru atau perancangan bahan pengajaran. Petak ini merupakan urutan pengajaran. Urutan pengajaran memperhatikan: 1) nama konsep; 2) atribut-atribut kriteria dan atribut-atribut variabel dari konsep; 3) definisi konsep; 4) contoh-contoh dan non contoh dari konsep; dan 5) hubungan konsep dengan konsep-konsep lain (Dahar, 1989: 
113). Khusus untuk nama konsep biasanya dicetak tebal atau miring (Dahar, 1989: 109).

Setiap siswa memulai kegiatan belajar dengan mempelajari peta konsep, diteruskan dengan peta prosedur, dan setelah itu mengerjakan latihan. Dalam mengerjakan latihan, siswa yang tidak mendapatkan kesukaran pada satu butir soal, dapat mengerjakan butir soal berikutnya. Tetapi jika mereka memperoleh kesukaran mereka harus mempelajari kembali peta konsep dan peta prosedur.

Pada strategi konvensional, pengorganisasian dengan buku teks, penyampaiannya oleh guru, dan pengelolaan kelas dengan guru sebagai nara sumber dan siswa mencatat bahan yang penting kemudian diakhiri dengan mengerjakan latihan. Strategi konvensional dalam penelitian ini adalah suatu strategi pembelajaran yang pada pengorganisasian menggunakan buku teks, penyampaian menggunakan catatan dari guru, dan pada strategi pengelolaan menekankan tanggung jawab guru untuk menjelaskan bahan pengajaran kepada siswa, sedangkan aktivitas siswa terutama mengikuti penyajian bahan pengajaran dari guru serta mengerjakan latihan yang sudah ada dalam buku teks. Jadi dapat ditarik kesimpulan bahwa strategi konvensional adalah cara mengajar pada materi tertentu yang bahan ajarnya dari buku teks yang sudah tersedia dan peran guru adalah menjelaskan materi pelajaran serta diselingi tanya jawab sedangkan siswa mendengar dan mencatat keterangan guru.

\section{Bentuk Tes Formatif}

Di lihat dari tujuan dan fungsinya tes dibagi menjadi empat, yaitu: 1) tes penempatan, 2) tes formatif, 3) tes diagnosis, dan 4) tes sumatif (Daryanto, 2001: 11). Dalam penelitian ini jenis tes yang digunakan adalah tes formatif yang disajikan di tengah program pengajaran, diharapkan untuk dapat memonitor kemajuan belajar siswa dan memberikan umpan balik, baik kepada siswa maupun kepada guru. Berdasarkan hasil tes tersebut guru dan siswa dapat mengetahui apakah masíh ada yang perlu dijelaskan kembali materi yang sudah disampaikan agar dapat dikuasai dengan baik.

Secara umum terdapat empat tipe objektif, yakni: soal jawaban singkat (short-answer or completion), pilihan ganda (multiple choice), benarsalah (true-false), dan menjodohkan (matching) (Aiken, 1997: 30). Penelitian ini menggunakan bentuk tes pilihan ganda. Hal ini disebabkan: 1) tipe tes di susun dan digunakan untuk mengukur semua standar kompetensi, mulai dari yang paling sederhana sampai yang paling kompleks; 2) jumlah alternatif jawaban (option) lebih dari dua sehingga dapat mengurangi keinginan siswa untuk menebak (guessing); 3) tipe tes ini menuntut kemampuan siswa untuk membedakan berbagai tingkatan kebenaran sekaligus; dan 4) tingkat kesukaran butir soal dapat dikendalikan dengan hanya mengubah tingkat homogenitas alternatif jawaban. Bentuk tes formatif pilihan ganda di skor secara objektif, karena pemeriksaannya atau penskorannya tidak selalu dilakukan oleh manusia tapi dapat dilakukan mesin misalnya mesin scanner.

Tes uraian lebih efektif digunakan pada tingkat tinggi seperti analisis, sintesis dan evaluasi. Bukan berarti tes uraian tidak efektif untuk mengukur hasil belajar tingkat rendah (Wiersma, 1990: 72). Tes uraian dalam kegiatan belajar mengajar matematika bermanfaat untuk: 1) mengungkapkan kemampuan intelektual tinggi, sebab siswa mengorganisasikan kemampuannya untuk menemukan jawaban dengan menggunakan kata-katanya sendiri; 2) mengungkapkan cara berpikir matematika, namun tes yang soalnya adalah membuktikan teorema yang sudah diajarkan akan mendorong siswa untuk menghafalnya saja; dan 3) mendorong siswa untuk terbiasa dalam menentukan langkah penyelesaian masalah disertai dengan alasannya. Bentuk tes formatif uraian dalam penelitian ini adalah seperangkat tes yang menuntut siswa menjawabnya dalam bentuk menguraikan, menjelaskan, mendiskusikan, membandingkan, memberikan alasan dan bentuk lain yang sejenis sesuai dengan tuntutan pertanyaan-pertanyaan yang menggunakan kata-kata dan bahasa sendiri.

\section{Inteligensi}

Inteligensi adalah potensi yang berpengaruh pada kemampuan berpikir seseorang sebagai salah satu aktivitas mental yang menjadi latar belakang perilaku. Menurut Stern, inteligensi adalah daya menyesuaikan diri dengan keadaan 
baru dengan mempergunakan alat-alat berpikir menurut tujuannya (Sternberg, 2000: 81). Inteligensi yang menitikberatkan pada soal penyesuaian diri (adjustment) seseorang pada masalah yang dihadapi. Sehingga orang yang inteligensinya tinggi (sering di sebut orang cerdas), lebih cepat menyesuaikan diri dengan masalah baru yang dihadapinya, bila dibandingkan dengan orang yang tidak cerdas.

Penggunaan tes untuk menilai inteligensi seorang anak, memiliki standar atau ukuran tersendiri, yaitu: a) IQ > 130 digolongkan dalam genius; b) IQ: 120 - 129 digolongkan dalam sangat pandai; c) IQ: 110 - 119 digolongkan dalam pandai; d) IQ: 90 - 109 digolongkan dalam normal; e) IQ: 80 - 89 digolongkan dalam bodoh; f) IQ: 70 - 79 digolongkan dalam dungu; g) IQ: 30 - 69 digolongkan dalam luar biasa; dan h) IQ $<25$ digolongkan dalam idiot (Arikunto, 2005: 14).

Tes untuk menilai inteligensi siswa, salah satunya adalah Tes Inteligensi Binet-Simon (Binet Simon Intelligence Test). Tes ini untuk mengukur tiga aspek yaitu aspek kecerdasan, kepribadian dan arah minat. Untuk aspek kecerdasan terbagi lagi dari 7 kemampuan yaitu: 1) kemampuan dalam ruang tiga dimensi; 2) kemampuan dasar abstraksi; 3) kemampuan bahasa; 4) kemampuan dasar berhitung; 5) kemampuan praktis dan logika; 6) potensi verbal/kapasitas belajar, berhubungan erat dengan prestasi belajar yang di capai di sekolah; dan 7) ketelitian/kecepatan kerja, (Java, 2007: 1 - 2). Tes kecerdasan ini yang digunakan lembaga psikologi untuk menilai hasil tes inteligensi siswa pada sekolah-sekolah.

Inteligensi dalam penelitian ini adalah skor yang diperoleh dari tes IQ (Intelligence Quotient) yang di buat dan di nilai oleh lembaga yang berwenang dilakukan pada saat siswa di kelas tujuh, baik siswa Sekolah Menengah Pertama (SMP) Negeri 11 Jakarta maupun siswa SMP Negeri 19 Jakarta. Instrumen tes inteligensi tidak dapat diperlihatkan pada disertasi ini karena milik lembaga psikologi yang tidak boleh diperlihatkan kepada umum. Ketika mereka di kelas delapan, data skor inteligensinya masih tetap ada. Berdasarkan data skor inteligensi itulah, peneliti memperoleh data untuk dijadikan salah satu variabel.

\section{Metodologi Penelitian}

Penelitian ini dilaksanakan di SMP Negeri 11 Jakarta dan SMP Negeri 19 Jakarta. Penelitian ini menggunakan tiga variabel bebas dan satu variabel terikat. Variabel bebas pertama adalah strategi pembelajaran yang berperan sebagai variabel perlakuan yang di bagi atas dua taraf yaitu strategi pemetaan informasi dan strategi konvensional. Variabel bebas kedua adalah bentuk tes formatif yang berperan sebagai variabel perlakuan yang di bagi atas dua taraf yaitu bentuk tes formatif pilihan ganda dan bentuk tes formatif uraian. Variabel bebas ketiga adalah inteligensi yang berperan sebagai covariable atau covariate. Inteligensi ini merupakan skor yang diperoleh siswa setelah mengikuti tes inteligensi yang dibuat dan di skor oleh lembaga psikologi. Variabel terikat adalah hasil belajar matematika. Hasil belajar ini merupakan skor yang diperoleh siswa setelah mengikuti tes hasil belajar yang diadakan setelah perlakuan eksperimen. Skor inteligensi siswa dihubungkan dengan skor hasil belajar matematika siswa, dari hubungan kedua skor tersebut akan di lihat pengaruh strategi pembelajaran dan bentuk tes formatif setelah diberikan kepada siswa. Desain eksperimen ditunjukkan pada Tabel 1 yang terlihat di bawah ini:

Tabel 1. Desain Eksperimen "Treatment-by-Level" $2 \times 2$

\begin{tabular}{|c|c|c|c|c|c|c|}
\hline & \multicolumn{3}{|c|}{ STRATEGI PEMBELAJARAN } & \multirow{2}{*}{\multicolumn{2}{|c|}{ TOTAL }} \\
\hline & & $\begin{array}{c}\text { PEMETAAN } \\
\text { INFORMASI } \\
\left(\mathrm{A}_{1}\right)\end{array}$ & \multicolumn{2}{|c|}{$\begin{array}{l}\text { KONVEN- } \\
\text { SIONAL } \\
\left(\mathrm{A}_{2}\right)\end{array}$} & & \\
\hline \multirow{3}{*}{$\begin{array}{c}\text { BENTUK } \\
\text { TES } \\
\text { FORMATIF }\end{array}$} & $\begin{array}{c}\text { PILIHAN } \\
\text { GANDA }\left(B_{1}\right)\end{array}$ & $\mathrm{X}_{11} \mathrm{Y}_{11}$ & $\mathrm{X}_{21}$ & $Y_{21}$ & $\mathrm{X}_{.1}$ & $\overline{Y .1}$ \\
\hline & URAIAN $\left(B_{2}\right)$ & $\mathrm{X}_{12}$ & $x_{22}$ & $Y_{22}$ & $\mathrm{X} .2$ & $\mathrm{Y}$. \\
\hline & DTAL & $\mathrm{X}_{1}$ & $x_{2}$ & $Y_{2}$ & $x$ & $\mathrm{Y}$ \\
\hline
\end{tabular}

Keterangan:

$X=$ Skor Inteligensi Siswa. $\quad Y=$ Skor Hasil Belajar Matematika 
Perlakuan penelitian yang dilakukan pada siswa dengan menggunakan strategi pembelajaran yaitu strategi pemetaan informasi pada kelompok eksperimen dan strategi konvensional pada kelompok kontrol. Kemudian kelompok eksperimen dan kelompok kontrol diberikan bentuk tes formatif yaitu bentuk tes pilihan ganda dan uraian secara bersamaan.

Strategi pemetaan informasi adalah strategi yang dilakukan guru pada proses belajar mengajar dengan 3 strategi yaitu: 1) pengorganisasiannya membuat bahan ajar yang memuat peta konsep dan peta prosedur dan latihan; 2) penyampaiannya diberi bahan ajar berisi peta konsep dan peta prosedur; dan 3) pengelolaannya adalah guru sebagai pemberi arahan dan bimbingan pada siswa dan siswa menganalisis bahan belajar dan latihan.

Strategi konvensional adalah strategi yang digunakan guru pada saat proses belajar mengajar dengan 3 strategi yaitu: 1) pengorganisasiannya bahan ajar buku teks; 2 ) penyampaian adalah catatan yang diberikan guru; dan 3) pengelolaan adalah guru sebagai penyaji bahan pengajaran dan siswa mendengar dan mencatat serta latihan.

Bentuk tes formatif pilihan ganda adalah seperangkat tes dengan empat alternatif jawaban, jawaban secara garis besar, waktu siswa untuk membaca dan berpikir, kualitas tes ditentukan keterampilan penyusun tes, mudah menskornya, penyusun tes menunjukkan pengetahuan yang dimiliki dan membatasi siswa untuk berekspresi, memberikan kesempatan kepada siswa untuk menerka jawaban, distribusi skor ditentukan oleh tes.

Bentuk tes formatif uraian adalah seperangkat tes yang menuntut siswa untuk merencana- kan sendiri jawabannya dan menyatakan dengan kata-katanya sendiri, mengundang jawaban secara luas, waktu siswa untuk berpikir dan menulis, mudah persiapannya tetapi sulit menskornya, siswa bebas menjawab dan pemberi skor bebas memberi skor secara profesional, dapat menyatakan tugas siswa dengan pertimbangan yang kurang jelas, secara sengaja memungkinkan dorongan ekspresinya keluar, distribusi skor ditentukan oleh si pemberi nilai.

Instrumen hasil belajar matematika sebelum digunakan, diujicobakan terlebih dahulu untuk menentukan indeks kesukaran, daya pembeda, keefektifan alternatif jawaban, validitas dan reliabilitas. Digunakan setelah strategi pemetaan informasi dan bentuk tes formatif dilaksanakan sebagai perlakuan penelitian eksperimen dengan 30 butir soal.

Skor inteligensi di peroleh dari tes inteligensi yang dinyatakan dalam nilai Intelligence Quotient (IQ). Nilai IQ berdasarkan hasil tes inteligensi yang dilaksanakan lembaga psikologi.

Analisa data dengan analisis inferensial berupa ANKOVA dua jalur untuk menguji hipotesis yang dilanjutkan dengan uji lanjut (Neter, 1974: 703 - 717). Sebelum uji hipotesis, dilakukan uji persyaratan analisis data berupa Uji Normalitas dengan Uji Lilliefors, Uji Homogonitas dengan Uji Bartlett dan Uji- $F$ (Murwani, 2003/2004: 18 - 26), Uji Homogeneity Slopes (Agung, 2006: 249 - 253), dan Uji kelinearan regresi (Neter, 1985: 852).

\section{Hasil dan Pembahasan}

Hasil penelitian menunjukkan bahwa: 1) hasil belajar matematika siswa yang menggunakan strategi pemetaan informasi lebih tinggi dari pada hasil belajar matematika siswa yang mengguna-

Tabel 2. Perhitungan Ankova

\begin{tabular}{|c|c|c|c|c|c|c|c|c|c|c|}
\hline \multirow[b]{2}{*}{ No } & \multirow[b]{2}{*}{ Sumber Varians } & \multicolumn{3}{|c|}{ JK } & \multirow{2}{*}{$\begin{array}{c}\text { JK } \\
\text { Residu }\end{array}$} & \multirow[b]{2}{*}{$d b$} & \multirow{2}{*}{$\begin{array}{c}\text { RJK } \\
\text { Residu }\end{array}$} & \multirow[b]{2}{*}{$\mathrm{F}_{0}$} & \multicolumn{2}{|c|}{$F_{\text {tabel }}$} \\
\hline & & $\mathrm{x}$ & $\mathrm{Y}$ & $X Y$ & & & & & $a=0,05$ & $\begin{array}{l}A= \\
0,01\end{array}$ \\
\hline $\begin{array}{l}1 \\
2 \\
3\end{array}$ & $\begin{array}{l}\text { Antar Kolom } \\
\quad(A) \\
\text { Antar Baris (B) } \\
\text { Interaksi A x B }\end{array}$ & $\begin{array}{c}4794,721 \\
1,191 \\
1,779\end{array}$ & $\begin{array}{c}0,059 \\
272 \\
313,471\end{array}$ & $\begin{array}{c}-16,794 \\
18 \\
23,618\end{array}$ & $\begin{array}{c}1589,519 \\
246,692 \\
280,363\end{array}$ & $\begin{array}{l}1 \\
1 \\
1\end{array}$ & $\begin{array}{l}1589,519 \\
246,692 \\
280,363\end{array}$ & $\begin{array}{l}94,080 * \\
14,601 * \\
16,594 *\end{array}$ & 2,754 & 4,112 \\
\hline $\begin{array}{l}4 \\
5 \\
\end{array}$ & $\begin{array}{c}\text { Antar } \\
\text { Dalam } \\
\end{array}$ & \begin{tabular}{|l|}
4797,691 \\
8336,588 \\
\end{tabular} & $\begin{array}{l}585,529 \\
5375,529 \\
\end{array}$ & $\begin{array}{c}24,824 \\
5995 \\
\end{array}$ & $\begin{array}{l}2137,588 \\
1064,410 \\
\end{array}$ & $\begin{array}{c}3 \\
63 \\
\end{array}$ & $\begin{array}{l}712,529 \\
16,895 \\
\end{array}$ & $42,173 *$ & & \\
\hline 6 & Total & 13134,279 & 5961,059 & 6019,824 & 3201 & 66 & 48,515 & & & \\
\hline
\end{tabular}

Keterangan : $*=$ Signifikan 
kan strategi konvensional; 2) hasil belajar matematika yang menggunakan bentuk tes formatif pilihan ganda lebih rendah dari pada hasil belajar matematika yang menggunakan bentuk tes formatif uraian, setelah mengontrol inteligensi siswa; dan 3) pengaruh strategi pembelajaran dengan bentuk tes formatif. Hasil pengujian hipotesis disajikan pada Tabel 2 .

Jika $F_{0}>F_{\text {tabel }}$ pada taraf signifikan $\alpha=0,05$ berarti terdapat pengaruh yang signifikan antara sumber varians. Pada tabel terlihat $\mathrm{F}_{0}>\mathrm{F}_{\text {tabel }}$ untuk sumber varians antar kolom (antar strategi pembelajaran), antar baris (antar bentuk tes formatif), interaksi A x B, (antar strategi pembelajaran dan bentuk tes formatif) ini berarti terdapat pengaruh yang signifikan antara strategi pembelajaran, antara bentuk tes formatif dan adanya interaksi antara straegi pembelajaran dan bentuk tes formatif. Karena hasil yang diperoleh signifikan maka perlu dilanjutkan dengan uji lanjut dengan uji t ankova.

Hasil perhitungan uji lanjut dengan uji $t$ ankova pada tabel 3.

Tabel 3. Uji Lanjut Setiap Kelompok Hasil Belajar Matematika

\begin{tabular}{|c|c|c|}
\hline \multicolumn{1}{|c|}{$t_{\text {hitung }}$} & $t_{\text {tabel }}$ & Perhitungan \\
\hline$t_{1}=12,136$ & 1,670 & $\begin{array}{l}t_{1}>t_{\text {tabel }} \\
t_{2}>t_{\text {tabel }}\end{array}$ \\
$t_{2}=3,821$ & & \\
\hline
\end{tabular}

Jika $t_{i}=t_{\text {tabel }}$ pada taraf signifikan $\alpha=0,05$ berarti terdapat pengaruh yang signifikan antar kelompok hasil belajar matematika. Pada tabel terlihat $\mathrm{t}_{\mathrm{i}}>\mathrm{t}_{\text {tabel }}$ untuk kelompok hasil belajar matematika yang menggunakan strategi pembelajaran, dan kelompok hasil belajar matematika yang diberikan bentuk tes formatif, ini berarti hasil belajar matematika siswa yang menggunakan strategi pemetaan informasi lebih tinggi dari pada hasil belajar matematika siswa yang menggunakan strategi konvensional dan hasil belajar matematika siswa yang diberikan bentuk tes formatif uraian mempunyai pengaruh yang signifikan dari pada hasil belajar matematika siswa yang diberikan bentuk tes formatif pilihan ganda. Karena hasil yang diperoleh signifikan maka perlu dilanjutkan dengan uji perbedaan.
Hasil perhitungan uji perbedaan ditunjukkan pada Tabel 4.

Tabel 4. Uji Perbedaan Setiap Kelompok Hasil Belajar Matematika

\begin{tabular}{|l|l|l|l|l|}
\hline \multirow{2}{*}{$t_{\text {hitung }}$} & \multicolumn{3}{|c|}{$t_{\text {tabel }}$} & Perhi- \\
\cline { 2 - 5 } & $\alpha=0,05$ & $\alpha=0,10$ & $\alpha=0,15$ & tungan \\
\hline$t_{3}=1,243$ & & & & $t_{3}>t_{\text {tabel }}$ \\
$t_{4}=1,647$ & 1,693 & 1,308 & 1,054 & $t_{4}>t_{\text {tabel }}$ \\
$t_{5}=2,767$ & & & & $t_{5}>t_{\text {tabel }}$ \\
$t_{6}=0,095$ & & & & $t_{6}<t_{\text {tabel }}$ \\
\hline
\end{tabular}

Jika $t_{i}>t_{\text {tabel }}$ pada taraf signifikan á $=0,05$ berarti terdapat pengaruh yang signifikan. Pada tabel terlihat $t_{i}>t_{\text {tabel }}$ kecuali pada $t_{6}$, ini menunjukkan bahwa $t_{3}, t_{4}$, dan $t_{5}$ mempunyai pengaruh yang signifikan. Hal ini berarti bahwa: 1) Untuk siswa yang diberikan bentuk tes formatif pilihan ganda, hasil belajar matematika siswa yang mengguna-kan strategi pemetaan informasi lebih rendah dari pada hasil belajar matematika siswa yang meng-gunakan strategi konvensional setelah mengon-trol inteligensi siswa; 2) Untuk siswa yang diberikan bentuk tes formatif uraian, hasil belajar matematika siswa yang menggunakan strategi pemetaan informasi lebih tinggi dari pada hasil belajar matematika siswa yang menggunakan strategi konvensional setelah mengontrol inteligensi siswa; 3) Untuk siswa yang menggunakan strategi pemetaan informasi, hasil belajar matematika siswa yang diberikan bentuk tes formatif pilihan ganda lebih rendah dari pada hasil belajar matematika siswa yang diberikan bentuk tes formatif uraian setelah mengontrol inteligensi siswa; dan 4) Untuk siswa yang menggunakan strategi konvensional, hasil belajar matematika siswa yang diberikan bentuk tes formatif pilihan ganda lebih tinggi dari pada hasil belajar matema-tika siswa yang diberikan bentuk tes formatif uraian setelah mengontrol inteligensi siswa.

Hasil tersebut berdasarkan pengujian persyaratan analisis: 1) Uji normalitas, menunjukkan bahwa sampel penelitian berasal dari populasi yang berdistribusi normal; 2) Uji homogenitas, memiliki variansi populasi yang homogen; 3) $\mathrm{Uji}$ homogeneous slopes menyatakan bahwa inteligensi siswa mempunyai perbedaan yang signifikan terhadap hasil belajar matematika yang 
di bentuk oleh kedua faktor yaitu faktor strategi pembelajaran dan faktor bentuk tes formatif, dan (4) Uji kelinearan regresi, menunjukkan regresi signifikan.

Hasil pengujian hipotesis menunjukkan bahwa strategi pembelajaran dan bentuk tes formatif mempunyai pengaruh yang signifikan terhadap hasil belajar matematika siswa setelah mengontrol inteligensi siswa. Khusus untuk siswa yang menggunakan strategi konvensional tidak mempunyai pengaruh bersyarat yang signifikan terhadap hasil belajar matematika siswa. Hasil penelitian untuk siswa yang diberikan bentuk tes formatif uraian lebih cocok dengan menggunakan strategi pembelajaran pemetaan informasi. Kesimpulan ini dapat di lihat dari lebih besarnya rata-rata hasil belajar matematika siswa yang menggunakan strategi pemetaan informasi dibandingkan dengan hasil belajar matematika siswa yang menggunakan strategi konvensional jika diberikan bentuk tes formatif uraian dan faktor strategi pembelajaran mempunyai pengaruh bersyarat yang signifikan terhadap hasil belajar matematika siswa khusus yang diberikan bentuk tes formatif uraian serta faktor bentuk tes formatif mempunyai pengaruh bersyarat yang signifikan terhadap hasil belajar matematika siswa khusus untuk strategi pemetaan informasi.

Strategi pemetaan informasi ini adalah penghematan biaya penyediaan informasi dan penghematan waktu penyajian bahan pengajaran. Peta-peta informasi ini sesuai dengan kebutuhan akan bahan pengajaran yang dapat meningkatkan motivasi siswa. Peningkatan ini akan bermula dari sebuah ruang kelas yang dapat dilakukan oleh seorang guru. Peningkatan hasil belajar matematika ini diusahakan guru melalui pemusatan aktivitas belajar siswa. Aktivitas belajar siswa inilah yang terpenting, karena dengan aktivitas tersebut siswa menentukan sendiri apakah ia akan belajar atau tidak, apakah ia akan mengolah dan menyimpan informasi dengan pengertian, ataukah semata-mata aktif karena akan menghadapi ujian.

Bentuk tes formatif ini adalah terbiasanya siswa menyelesaikan soal-soal matematika yang di susun secara baik dan benar dan merasa tenang ketika menghadapi soal matematika yang lain termasuk soal matematika yang dibuat oleh penyusun soal tingkat nasional. Di lihat dari hambatannya memang sulit pada tahap penyusunan soal oleh guru, tetapi tidak sulit untuk digunakan kepada siswa sebagai bahan mereka untuk belajar berkompetisi dari bentuk tes pilihan ganda maupun bentuk tes uraian.

\section{Simpulan dan Saran Simpulan}

Strategi pemetaan informasi yang diterapkan pada mata pelajaran matematika cukup efektif untuk meningkatkan hasil belajar. Kekuatan strategi pemetaan informasi ini terletak pada bahan pengajaran yang memberikan kemudahan belajar pada siswa serta mampu mewujudkan aktivitas belajar siswa. Dengan demikian proses belajar mengajar mata pelajaran matematika akan terpusat kepada siswa dan peran guru akan terpusat kepada peran memberi arahan serta bimbingan belajar kepada siswa.

Berdasarkan hasil perhitungan statistika temuan penelitian dapat diuraikan sebagai berikut: 1) Hasil belajar matematika antara siswa yang menggunakan strategi pemetaan informasi lebih tinggi dari pada hasil belajar matematika siswa yang menggunakan strategi konvensional setelah mengontrol inteligensi siswa; 2) Hasil belajar matematika siswa yang diberikan bentuk tes formatif pilihan ganda lebih rendah dari pada hasil belajar matematika siswa yang diberikan bentuk tes formatif uraian setelah mengontrol inteligensi siswa; 3) Terdapat pengaruh interaksi antara strategi pembelajaran dan bentuk tes formatif terhadap hasil belajar matematika setelah mengontrol inteligensi siswa; 4) Untuk siswa yang diberikan bentuk tes formatif pilihan ganda, hasil belajar matematika siswa yang menggunakan strategi pemetaan informasi lebih rendah dari pada hasil belajar matematika siswa yang menggunakan strategi konvensional setelah mengontrol inteligensi siswa; 5) Untuk siswa yang diberikan bentuk tes formatif uraian, hasil belajar matematika siswa yang menggunakan strategi pemetaan informasi lebih tinggi dari pada hasil belajar matematika siswa yang menggunakan strategi konvensional setelah mengontrol inteligensi siswa; 6) Untuk siswa yang menggunakan strategi pemetaan informasi, hasil belajar matematika siswa yang diberikan bentuk tes formatif pilihan ganda lebih rendah dari pada hasil 
belajar matematika siswa yang diberikan bentuk tes formatif uraian setelah mengontrol inteligensi siswa; dan 7) Untuk siswa yang menggunakan strategi konvensional, hasil belajar matematika siswa yang diberikan bentuk tes formatif pilihan ganda lebih tinggi dari pada hasil belajar matematika siswa yang diberikan bentuk tes formatif uraian setelah mengontrol inteligensi siswa.

Jadi dengan menerapkan strategi pemetaan informasi dan bentuk tes formatif, seorang guru matematika dengan bekal kemauan, kemampuan, dan kreativitas dapat mengusahakan peningkatan pengajaran matematika tanpa menungggu adanya penyempurnaan kurikulum, penyediaan sarana dan biaya yang memadai yang selama ini di anggap kendala dalam meningkatkan mutu pendidikan. Walaupun penyempurnaan kurikulum, sarana serta biaya yang memadai itu selalu diperlukan, namun guru harus berusaha melakukan terobosan menghadapi hambatan itu, dengan demikian dapat diartikan bahwa peningkatan strategi pembelajaran matematika maupun bentuk formatif tidak berhenti walaupun banyak tantangan yang dihadapi guru.

\section{Saran}

Dalam meningkatkan hasil belajar matematika disarankan untuk guru khususnya guru matematika dapat menggunakan strategi pemetaan informasi selain menggunakan strategi konvensional yang selama ini sudah dilakukan, memberikan bentuk formatif tes tertulis dalam bentuk pilihan ganda maupun bentuk tes uraian.

Perlu dilakukan bimbingan kepala sekolah untuk meningkatkan kemampuan guru khususnya guru matematika dalam menyusun peta konsep dan peta prosedur yang akan dilaksanakan sebagai bahan pengajaran. Tujuannya adalah agar diperoleh bahan pengajaran yang memiliki keefektifan dalam meningkatkan hasil belajar matematika, dalam arti tidak hanya didasarkan kepada materi pelajaran akan tetapi juga melihat pada kemampuan penerimaan siswa dalam menerima bahan pengajaran. Apapun cara yang digunakan untuk mempersiapkan guru mata pelajaran matematika, suatu kompetensi yang sangat mendasar adalah mereka harus benarbenar menguasai materi pelajaran matematika yang akan disampaikan kepada siswa. Tanpa penguasaan materi pelajaran matematika tersebut mereka akan memperoleh hambatan dalam menyusun bahan pengajaran.

Perlu melakukan variasi bentuk tes formatif khususnya bentuk tes pilihan ganda dan bentuk tes uraian pada saat guru ingin melihat hasil belajar matematika siswa. Tujuannya adalah agar diperoleh bentuk tes formatif efektif dalam meningkatkan hasil belajar matematika selain itu untuk meningkatkan kepercayaan dirinya dalam menghadapi berbagai tes yang akan dihadapi terutama pada saat ulangan umum, ujian nasional atau ujian tingkat internasional.

Penelitian lanjutan menggeneralisasikan hasil penelitian pada populasi yang lebih luas, yang meliputi Sekolah Menengah Pertama Negeri yang berkualitas sebagai sekolah ungulan, sedang, dan kurang, maka perlu diadakan penelitian dengan menggunakan sampel berstrata. Penelitian ini dapat lebih diperluas dengan menggunakan populasi yang terdiri dari Sekolah Menengah Pertama Negeri dan Swasta dari berbagai daerah. Selain itu dapat pula diperluas suatu penelitian keefektifan pemetaan informasi atau keefektifan bentuk tes formatif terhadap berbagai variabel lainnya yang berkaitan dengan pelajaran matematika.

\section{PUSTAKA ACUAN}

Agung, Gusti Ngurah, 2006. Statistika Penerapan Model Rerata-Sel Multivariat dan Model Ekomoni dengan SPSS, Jakarta: Sad Satria Bhakti.

Aiken, Lewis R., 1997. Psychological Testing and Assessment, Boston: Allyn and Bacon.

Arikunto, S., 2005. Dasar-dasar Evaluasi Pendidik, Jakarta: Bumi Aksara.

Bloom, Benyamin S., J. Thomas Hastings and George F. Madaus, 1971. Handbook on Formative and Summative Evaluation of Student Learning, New York:Mc-Graw-Hill. Inc.

Dahar, Ratna Wilis, 1989.Teori-teori Belajar, Jakarta: Erlangga.

Daryanto, 2001. Evaluasi Pendidikan, Jakarta: Rineka Cipta. 
Departemen Pendidikan Nasional, 2003. Pedoman Khusus Pengembangan Silabus Berbasis Kompetensi Sekolah Menengah Pertama (SMP), Jakarta: Departemen Pendidikan Nasional. , 2008. Strategi Pembelajaran dan Pemilihannya, Jakarta: Departemen Pendidikan Nasional. 2006. Undang-undang Republik Indonesia Nomor 20 Tahun 2003 tentang Sistem Pendidikan Nasional, Jakarta: Departemen Pendidikan Nasional.

Horn, Robert E., 1996. Structured Writing as a Paradigm, Englewood Cliffs: Educational Technology Publications.

Java, Tri, 2007. Analisa Laporan Hasil Pemeriksaan Psikologi, Jakarta: Lembaga Psikologi Tri Java. Murwani, Santosa, 2003. Statistika Terapan, Jakarta: Program Pascasarjana UHAMKA.

Neter, John, and William Wasserman, 1985. Applied Linear Statistical Models Regression, Analysis of Variance, and Experimental Designs, Illinois: Richard D. Irwin, Inc.

Sadiman, Arief S., 2002. Media Pendidikan: Pengertian, Pengembangan dan Pemanfaatannya, Jakarta: Pustekom Depdikbud dan Raja Grafindo Persada.

Soedjadi, R., 2000. Kiat Pendidikan Matematika di Indonesia, Jakarta: Departemen Pendidikan Nasional.

Sternberg, Robert J., 2004. "Teori Kognitif", Psikologi Pendidikan, Djaali (ed) Jakarta: Program Pascasarjana Universitas Negeri Jakarta.

Wiersma, William and Stephen G. Jurs, 1990. Educational Measurement and Testing, Toronto: Allyn and Bacon.

Woolfolk, A. E., 1993. Educational Psychology, Boston: Allyn and Bacon, Inc.

Undang-Undang Republik Indonesia Nomor 20 Tahun 2003 Tentang Sistem Pendidikan Nasional. 